\title{
The parental career-related behaviors questionnaire (PCB): Psychometric properties in adolescents and young adults in the Italian context
}

\author{
Anna Parola ${ }^{1}\left[\right.$ Luca Fusco $^{1} \cdot$ Jenny Marcionetti ${ }^{2}$
}

Accepted: 20 January 2022

(c) The Author(s) 2022

\begin{abstract}
Over the last few years, the role of parental career-related behaviors in career development has been identified in several studies. Specifically, these behaviors involve difficulties in the adolescents' career decision-making. In the literature, there is a validated scale for measuring parental career-related behaviors in the Italian language, but the validation refers to the Swiss context. Thus, the present study aimed to test the psychometric proprieties of the parental career-related behaviors questionnaire (PCB) in a sample of 323 adolescents and, after an item-adaption, in a sample of 374 university students in Italy. Confirmatory factor analyses were performed to support the three-dimensional structure of the original PCB. Moreover, associations between PCB and career decision-making difficulties were investigated. The results showed that the PCB is a useful instrument for measuring parental career-related behaviors also in the Italian context. Finally, the PCB dimensions were meaningfully related to career decision-making difficulties.
\end{abstract}

Keywords Parental career-related behaviors · Career decision-making difficulties · Italian context validation · Confirmatory factor analysis

\section{Introduction}

The influence of parents on career development was acknowledged in several studies on adolescents and young people (Greenhaus \& Powell, 2006; Halpern, 2005; Hughes \& Thomas, 2003; Paa \& McWhirter, 2000; Schultheiss, 2006). Many studies on this issue have focused on the link between parental attachment and career development. The literature shows that secure attachment (Blustein et al., 1991), individuation (Grotevant \& Cooper, 1988), and authoritative parenting style (Tracey et al., 2006) are

Anna Parola

anna.parola@unina.it

Luca Fusco

luca.fusco@unina.it

Jenny Marcionetti

jenny.marcionetti@supsi.ch

1 Department of Humanities, University of Naples Federico II, Via Porta di Massa, 1, 80133 Naples, Italy

2 University of Applied Sciences and Arts of Southern Switzerland, Locarno, Switzerland associated with greater exploration of career possibilities (Grotevant \& Cooper, 1988; Kracke, 1997; Vignoli et al., 2005), career search self-efficacy (Ryan et al., 1996) and a facilitated development in the construction of professional identity (Johnson et al., 1999; Penick \& Jepsen, 1992; Tracey et al., 2006). On the contrary, family conflicts and dysfunctions are negatively associated with career search self-efficacy and the development of professional identity (Hargrove et al., 2002, 2005; Johnson et al., 1999; Ryan et al., 1996).

Other studies focused on the effects of parental support on career development. These studies showed that parental support increased self-efficacy in career decision-making (Kush \& Cochran, 1993; Lent et al., 2003; Wolfe \& Betz, 2004), vocational adaptability (Kenny \& Bledsoe, 2005), career exploration (Kracke, 1997), and decreased career indecision (Guerra \& Braungart-Rieker, 1999). In this sense, parents can be a precious resource for the individual in transition (i.e., transition between educational systems or school-towork transitions), providing instrumental and emotional support (Marcionetti \& Rossier, 2016). Likewise, families could be a risk factor or an obstacle for career choices (Zhao et al., 2012). 
The role of the family in career development is central both in adolescents (Keller \& Whiston, 2008) and in young adults ( $\mathrm{Li}$ et al., 2015). Most studies focus on the period between adolescence and the first career choice. It is during their teenage that students begin to explore job opportunities, develop aspirations and occupational expectations that are increasingly concrete (Hartung et al., 2005), formulate expectations of self-efficacy (Turner \& Lapan, 2005), and crystallize their interests (Tracey \& Darcy, 2002). Their family can then be a resource in career decision-making, in terms of both support and motivation for choice (Fouad et al., 2010; Guay et al., 2006; Keller \& Whiston, 2008; Neuenschwander, 2008; Whiston \& Keller, 2004).

Recently, Marcionetti and Rossier (2016) have validated in the Italian-language Dietrich and Kracke's instrument (2009) constructed to assess parental career-related behaviors, PCB. Parental career-related behaviors refer to those that parents put into practice to orient their children's career development. Three parental behaviors of career orientation were considered: (a) career-related support, i.e. instrumental support for the choice; (b) interference behavior, i.e. an obstacle to the normal process of choice-making, (c) parental lack of engagement, i.e. no support (concerning lack of interest, poor financial support, scarce time spent with their children). From the first version of the test that measured three parental behaviors with 32 items, the final version contained 15 items, five for each scale. This instrument was validated in a sample of 359 (158 female and 201 male) German adolescents aged $15-18$ years $(\mathrm{M}=15.9, \mathrm{SD}=0.95)$ (Dietrich \& Kracke, 2009). In the Italian validation on 481 Swiss adolescents, the confirmatory factor analysis supported the original three-dimensional structure of the PCB.

Furthermore, Dietrich and Kracke (2009) examined the extent to which parents' career-related behaviors are associated with adolescents' career development, taking into account career decision-making. Dietrich and Kracke (2009) found that the interference and lack of engagement dimensions were associated with career indecision, in accordance with previous research (Guay et al., 2003; Kracke \& Noack, 2005). In their validation study, Marcionetti and Rossier (2016) investigated the relationship between the support provided by parents, based on the three dimensions analyzed by Dietrich and Kracke (2009), and difficulties in career decision-making, based on the taxonomy proposed by Gati and colleagues (Gati et al., 1996). Such taxonomy features three major categories of difficulty, which are further divided into ten categories. It includes Lack of Readiness, which includes lack of motivation to engage in the career decision-making process, general indecisiveness concerning all types of decisions, and dysfunctional beliefs; Lack of Information, which includes lack of knowledge about the steps involved in the process, lack of information about the self, lack of information about the various alternatives, and lack of information about the ways of obtaining additional information; Inconsistent Information, which includes unreliable information, internal and external conflicts.

To our knowledge, there are no studies that have tested the psychometric properties of the PCB in the Italian context. This study proposes to fill the gap argued by Marcionetti and Rossier (2016) testing and extending the applicability of PCB to the Italian teenage population. Moreover, no studies have adapted the PCB for Italian young adults. We believe that it is necessary to study the perception of parental career-related behavior also in university students, who are involved in the school-to-work transition; indeed, the literature underlines the key role of parents in career choices also in this phase (Li et al., 2015). Adapting and validating the PCB measure to this population can be useful for career researchers and practitioners.

Taking this rationale into account, this paper presents two studies. Study I focuses on testing the Italian version of the PCB by Marcionetti and Rossier (2016) with Italian adolescents. Study 2 focuses on PCB item-adaptation and validation for Italian university students.

\section{Study I}

This study aimed to test the Italian version of the PCB in the Italian context assessing its three-dimensional structure (support, interference, and lack of engagement) and internal consistency. Moreover, we investigated the relationships between parental career-related behaviors and career decision-making difficulties to assess the criterion validity by studying the extent to which these behaviors were related to specific career choice outcomes. Based on the results obtained by Marcionetti and Rossier (2016), we expected parental support to be negatively associated with lack of readiness, lack of information and inconsistency of information; on the other hand, we expected parental interference and lack of engagement to be positively associated with lack of readiness, lack of information and inconsistency of information.

\section{Methods}

\section{Participants and Procedure of Data Collection}

The sample consisted of 323 adolescents, 183 males, and 140 females. The total sample included 182 students in middle school, 89 boys and 93 girls $\left(\mathrm{M}_{\mathrm{age}}=13.14, \mathrm{SD}_{\mathrm{age}}=0.36\right)$ and 141 students in high-school, 94 boys and 47 girls $\left(\mathrm{M}_{\mathrm{age}}=18.38, \mathrm{SD}_{\mathrm{age}}=0.54\right)$. The data collection was carried out in the Campania Region, in Southern Italy. The 
adolescents involved filled in the questionnaires in their classroom in the presence of the first author. In compliance with ethical standards, informed consent was requested from the middle school and high school principals and the students' parents. The participants were asked to read the questionnaire instructions before beginning their self-evaluation. The purpose of the informed consent form was to provide confidentiality and anonymity for the study participants. The study was carried out following the American Psychological Association rules, and it was also approved by the Ethical Committee of Psychological Research of the University of Naples Federico II.

\section{Measures}

\section{Parental Career-Related Behaviors Questionnaire (PCB)}

This instrument consists of 15 items assessing three specific parental behaviors in their children's career choices. The PCB includes three types of influence: (I) Support (5 items, e.g. "My parents give advice on the choice of careers available"), (II) Interference (5 items, e.g. "My parents have their own ideas about my future vocation and try to influence me accordingly"), and (III) Lack of Engagement (5 items, e.g. "My parents cannot support my vocational preparation, because they are too busy"). Participants responded to each item on a 4-point scale from 1 (=does not apply) to 4 (=fully applies). The three dimensions are defined as the mean of the items belonging to them (range 1-4). Higher mean scores of Support indicate that children receive encouragement from parents to explore their career possibilities and provide advice whenever necessary. Higher mean scores of Interference indicate that children perceive intrusive control and imposed preferences from their parents in career preparation and career aspirations. Higher mean scores of Lack of Engagement refer to parents' inability or reluctance to get involved in their children's career development. The internal reliability of the German scale was 0.84 for Support, 0.72 for Interference, and 0.68 for Lack of Engagement. Cronbach's alphas of reliability of the Italianversion were respectively $0.82,0.82$, and 0.90 . In this study, we used the version translated into Italian by Marcionetti and Rossier (2016).

\section{Career Decision-Making Difficulties Questionnaire (CDDQ)}

This instrument consists of 34 items assessing career indecision (Gati et al., 1996). For this study, we used the Italian-validated version (Di Fabio \& Palazzeschi, 2013).
Participants responded to each item on a 9-point scale from 1 (=does not describe me) to 9 (=describes me well) concerning how much the difficulty proposed by each item describes them. Three dimensions are included: (I) Lack of Readiness (10 items, e.g. "It is usually difficult for me to make decisions"), (II) Lack of Information (10 items, e.g. "I find it difficult to make a career decision because I do not know what factors to take into account"), and (III) Inconsistency of Information (10 items, e.g. "I find it difficult to make a career decision because I have contradictory data about the existence or the characteristics of a particular occupation or training program"). Each scale includes three or four subscales. The first dimension includes lack of motivation (3 items), indecisiveness (3 items), and dysfunctional myths (4 items). The second dimension includes lack of information about the career decision-making process ( 3 items), lack of information about the self (4 items), lack of information about the various alternatives ( 3 items), and lack of information about the ways of obtaining additional information (2 items). The third dimension includes unreliable information (3 items), internal conflicts (5 items), and external conflicts ( 2 items). Two of these are validity items (item 7 and item 12). The ten difficulty category scores (as well as the three major categories and the total CDDQ scores) are defined as the mean of the items belonging to them (range 1-9). Higher mean scores of Lack of Readiness refer to difficulties before entering the career decision-making processes. Higher mean scores of Lack of Information indicate difficulties to obtain information about careers. Higher mean scores of Inconsistent Information refer to unreliable information and/or internal/external conflicts. Cronbach's alphas of reliability of the Italian version were 0.87 for Lack of Readiness, 0.89 for Lack of Information, and 0.91 for Inconsistency of Information. For this study, Cronbach's alphas for the four subscales were $0.63,0.92$ and 0.87 .

\section{Data Analysis}

A Confirmatory Factor Analysis (CFA), applying the weight least square adjusted for mean and variance (WLSMV) was performed to assess the structural validity of the threedimensional structure of the PCB instrument. Analyses were run in Mplus 8.0. A model is considered to have a satisfactory fit if the comparative fit index (CFI), and the Tucker-Lewis index (TLI) values are approximately 0.90 or above (Medsker et al., 1994); and if the root means square error of approximation (RMSEA) is approximately 0.08 or less (Byrne, 2010). Correlations between PCB dimensions and career decision-making difficulties were computed to test the criterion validity of the instrument. Moreover, correlations between age and all dimensions of PCB and CDDQ were performed. 


\section{Results}

The model was found to adequately fit the data, $\chi^{2}(87)=231.043, p<0.001 ; \mathrm{TLI}=0.951 ; \mathrm{CFI}=0.959$; RMSEA $=0.072$. These values confirmed the adequacy of the three-dimensional structure of the PCB instrument. Item means, standard deviations and standardized factor loadings are reported in Table 1 . The factor loadings vary from 0.57 to 0.90 confirming the soundness of the items used to measure the dimensions. A positive association emerged between Lack of Engagement and Interference (estimated factor correlation 0.60) and a negative association emerged between Support and Lack of Engagement (estimated factor correlation -0.32). A graphical representation is provided in Fig. 1. These last results suggest discriminant validity of the instrument (Kline, 2011). Cronbach's alphas for each scale confirmed the reliability of the measures used: it was 0.71 for Support, 0.84 for Interference, and 0.87 for Lack of Engagement.

The associations between age, parental career-related behaviors and career decision-making difficulties are shown in Table 2. Age correlated negatively with the Support and Lack of Readiness and positively with Interference and Lack of Engagement. All coefficients are not high. No associations were found between age and other dimensions of career decision-making difficulties. Interference and Lack of Engagement were positively associated with Lack of Readiness, Lack of Information, Inconsistence of Information and the total score of CDDQ. Moreover, all the dimensions of the CDDQ were strongly positively correlated.

\section{Brief Discussion}

The three-factor model of the 15-item PCB provided a very good fit to the data and all items loaded significantly on their respective latent factors. The good Cronbach's $\alpha$ s confirmed the internal consistency of the instrument. The Italian-version of the PCB, therefore, proves to be valid for adolescents in the Italian context.

\section{Study II}

This second study aimed to adapt the measure previously tested in a sample of adolescents (Study I) for young adults, assessing its three-dimensional structure (support, interference, and lack of engagement) and internal consistency.

Our adaption was carried out in a two-step procedure. Initially, the first and the second Authors, considering the Italian education system and the target population, made semantic changes regarding five items which were reformulated to capture the career choices. After that, a debriefing with five young adults was performed as a linguistic validation process to confirm that the items were clearly expressed and understandable. We adapted items 11, 12, 13, 14 and 15 which contained the words "vocational preparation", which in the Italian version were translated into "formazione professionale": we changed them into "formazione o carriera" for young adults. Moreover, item 3-"My parents support me in getting an apprenticeship" was changed into "My parents support me in getting a job or post-university
Table 1 Means, standard deviations of each items and results of CFA in adolescents population (Study 1)

\begin{tabular}{|c|c|c|c|c|c|c|c|c|}
\hline & M & SD & $\mathrm{Sk}$ & K & $S(\lambda)$ & $\mathrm{I}(\lambda)$ & $\operatorname{LE}(\lambda)$ & $\mathrm{R}^{2}$ \\
\hline Item 1 & 2.92 & 1.04 & -0.568 & -0.857 & $.57 *$ & & & .33 \\
\hline Item 2 & 3.23 & 0.93 & -0.917 & -0.256 & $.78 *$ & & & .61 \\
\hline Item 3 & 3.19 & 0.91 & -0.930 & -0.003 & $.60 *$ & & & .36 \\
\hline Item 4 & 3.29 & 0.89 & -1.167 & 0.548 & $.66^{*}$ & & & .44 \\
\hline Item 5 & 2.93 & 0.96 & 0.577 & -0.617 & $.58 *$ & & & .33 \\
\hline Item 6 & 2.04 & 1.10 & 0.590 & -1.035 & & $.69 *$ & & .47 \\
\hline Item 7 & 1.73 & 1.02 & 1.142 & -0.041 & & $.84 *$ & & .70 \\
\hline Item 8 & 1.87 & 1.09 & 0.840 & -0.747 & & $.86^{*}$ & & .74 \\
\hline Item 9 & 1.70 & 0.99 & 1.154 & 0.052 & & $.82 *$ & & .67 \\
\hline Item 10 & 1.88 & 1.07 & 0.835 & -0.696 & & $.78^{*}$ & & .61 \\
\hline Item 11 & 1.57 & 1.01 & 1.510 & 0.730 & & & $.84 *$ & .70 \\
\hline Item 12 & 1.56 & 1.01 & 1.567 & 0.952 & & & $.87^{*}$ & .75 \\
\hline Item 13 & 1.69 & 0.98 & 1.125 & -0.060 & & & $.78^{*}$ & .62 \\
\hline Item 14 & 1.61 & 0.94 & 1.374 & 0.656 & & & $.91^{*}$ & .82 \\
\hline Item 15 & 1.64 & 1.00 & 1.346 & 0.565 & & & $.87 *$ & .76 \\
\hline
\end{tabular}

$M$ means, $S D$ standard deviations, $S$ Support, $I$ Interference, $L E$ Lack of Engagement, $S k$ Skewness, $K$ Kurtosis, $\lambda$ factor loading

$* p<.001$ 


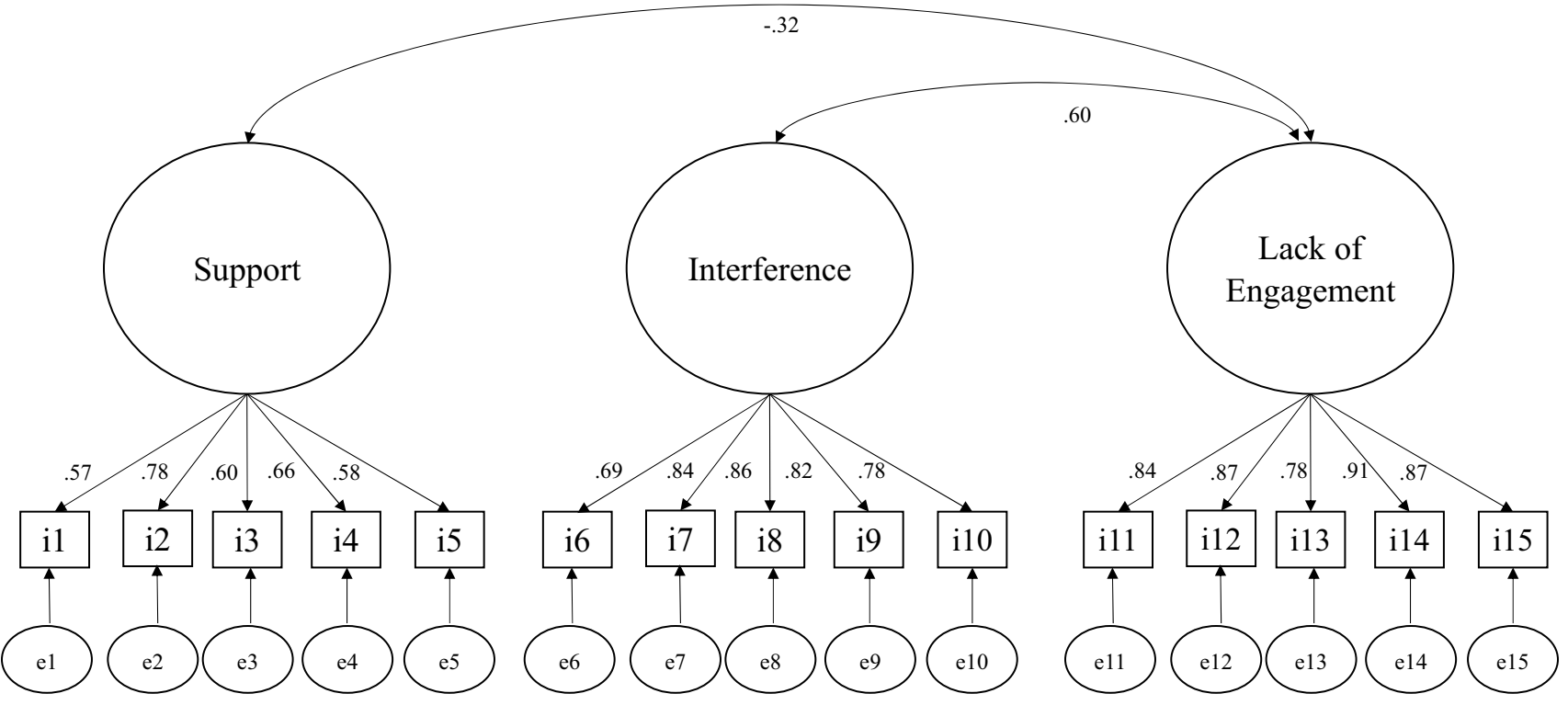

Fig. 1 Graphical representation of the three-dimensional structure of PCB tested with CFA (adolescents' population)

specialization". The purpose of the modifications was to allow the items to address also the perception of parental behavior on job choices and not only on apprenticeship and future vocation. Indeed, at the end of university, students can choose between moving to the world of work or continuing their education/training. After that, all changed items were discussed again within the study group until a new version of the questionnaire was agreed upon for young adults.

To assess the criterion validity, the study analyzed the relationships between the three dimensions of parental career-related behaviors (support, interference, lack of engagement) and the three dimensions of career decisionmaking difficulties (lack of readiness, lack of information, inconsistency of information). We hypothesized parental support to be negatively associated with the three dimensions of career decision-making difficulties, while parental interference and parental lack of engagement to be positively associated with the three dimensions of career decisionmaking difficulties.

\section{Methods}

\section{Participants and Procedure of Data Collection}

The sample consisted of 374 young adults $\left(\mathrm{M}_{\mathrm{age}}=23.16\right.$; $\left.\mathrm{SD}_{\mathrm{age}}=3.28\right), 112$ males, and 262 females. The university

Table 2 Means, standard deviation, and correlations matrix in adolescents population

\begin{tabular}{|c|c|c|c|c|c|c|c|c|c|c|c|}
\hline & 1 & 2 & 3 & 4 & 5 & 6 & 7 & 8 & $\mathrm{M}(\mathrm{SD})$ & $\mathbf{M}_{\text {male }}$ & $\mathbf{M}_{\text {female }}$ \\
\hline 1. Age & - & & & & & & & & - & - & - \\
\hline 2. PCB S & $-.118^{*}$ & - & & & & & & & $3.11(0.65)$ & $3.08(0.65)$ & $3.15(0.64)$ \\
\hline 3. PCB I & $.218^{* *}$ & .026 & - & & & & & & $1.84(0.82)$ & $2.04(0.83)$ & $1.59(0.73)$ \\
\hline 4. PCB LE & $.240 * *$ & $-.220 * *$ & $.484 * *$ & - & & & & & $1.61(0.80)$ & $1.80(0.92)$ & $1.37(0.52)$ \\
\hline 5. CDDQ LR & $-.118^{*}$ & .088 & $.196^{* *}$ & $.204 * *$ & - & & & & $4.55(1.27)$ & $4.45(1.26)$ & $4.69(1.28)$ \\
\hline 6. CDDQ LI & .023 & -.098 & $.205^{* *}$ & $.212 * *$ & $.608 * *$ & - & & & $3.82(1.79)$ & $3.84(1.76)$ & $3.80(1.83)$ \\
\hline 7. CDDQ II & .056 & -.071 & $.371 * *$ & $.323 * *$ & $.594 * *$ & $.744 * *$ & - & & $3.44(1.70)$ & $3.51(1.74)$ & $3.35(1.64)$ \\
\hline 8. CDDQ & -.002 & -.044 & $.298 * *$ & $.284 * *$ & $.803 * *$ & $.912 * *$ & $.904 * *$ & - & $3.94(1.39)$ & $3.93(1.38)$ & $3.95(1.42)$ \\
\hline
\end{tabular}

PCB S Parental Career-related Behaviors Support, PCB I Parental Career-related Behaviors Interference, PCB LE Parental Career-related Behaviors Lack of engagement, $C D D Q$ Career Decision-making Difficulties Questionnaire with $L R$ Lack of readiness $L I$ Lack of information and $I I$ Inconsistence of information, $M$ Mean, $S D$ Standard Deviation

$* p<.01, * * p<.001$ 
students involved filled out the questionnaire booklet at the end of a lesson with the presence of the first author. Consents were obtained before the administration of the questionnaires, provided a complete guarantee of confidentiality and anonymity. Like in the previous study, the approval of the Ethical Committee of Psychological Research of the University of Naples Federico II was obtained for collecting the data.

\section{Measures}

In this study, we used the 15 items adapted from the PCB validated by Marcionetti and Rossier (2016) and the CDDQ by Di Fabio and Palazzeschi (2013)—-(see the Measures section of Study I).

\section{Data Analysis}

As in Study I, CFA and correlations between age, PCB dimensions and career decision-making difficulties were performed.

\section{Results}

The model was found to adequately fit the data, $\chi^{2}(87)=522.830$, $p<0.001 ; \mathrm{TLI}=0.952 ; \mathrm{CFI}=0.941 ; \mathrm{RMSEA}=0.071$. These values confirmed the adequacy of the three-dimensional structure of the instrument. Item means, standard deviations and standardized factor loadings are reported in Table 3 . The factor loadings varied from 0.63 to 0.92 confirming the soundness of the items used to measure the dimensions. A negative association emerged between Support and Lack of Engagement (estimated factor correlation -0.62), and a weaker positive association emerged between Interference and Support (estimated factor correlation 0.17). A graphical representation is provided in Fig. 2. These results suggest the discriminant validity of the instrument (Kline, 2011). Cronbach's alphas of the three scales were 0.84 for Support, 0.86 for Interference and 0.74 for Lack of Engagement, confirming the reliability of the measures used.

The associations between age, parental career-related behaviors and career decision-making difficulties are shown in Table 4. Age correlated negatively with the Support and Lack of Information and positively with Interference and Lack of Engagement. All coefficients are not high. No associations were found between age and other dimensions of career decision-making difficulties. Support was negatively associated with Lack of Information, while Interference and Lack of Engagement were positively associated with Lack of Readiness, Lack of Information, Inconsistence of Information and the total score of CDDQ. Moreover, all the dimensions of the CDDQ were strongly positively correlated.

\section{Brief Discussion}

The three-factor model of the 15 adapted items provided a good fit to the data and all items loaded significantly on their respective latent factor. The good Cronbach's alpha

Table 3 Means, standard deviations of each items and results of CFA in young adults population (Study 2)

\begin{tabular}{|c|c|c|c|c|c|c|c|c|}
\hline & $\mathrm{M}$ & $\mathrm{SD}$ & $\mathrm{Sk}$ & $\mathrm{K}$ & $S(\lambda)$ & $\mathrm{I}(\lambda)$ & $\operatorname{LE}(\lambda)$ & $\mathrm{R}^{2}$ \\
\hline Item 1 & 2.36 & 1.09 & -0.053 & -1.187 & $.76^{*}$ & & & .58 \\
\hline Item 2 & 2.65 & 1.17 & -0.476 & -1.149 & $.82 *$ & & & .67 \\
\hline Item 3 & 2.46 & 1.16 & -0.056 & -1.349 & $.74 *$ & & & .55 \\
\hline Item 4 & 2.38 & 1.12 & -0.054 & -1.302 & $.83 *$ & & & .68 \\
\hline Item 5 & 1.91 & 1.03 & 0.532 & -0.983 & $.79 *$ & & & .63 \\
\hline Item 6 & 1.66 & 0.95 & 1.136 & 0.111 & & $.74 *$ & & .54 \\
\hline Item 7 & 1.40 & 0.81 & 1.788 & 1.495 & & $.84 *$ & & .70 \\
\hline Item 8 & 1.38 & 0.83 & 1.183 & 1.694 & & $.86^{*}$ & & .74 \\
\hline Item 9 & 1.30 & 0.67 & 1.220 & 1.400 & & $.90^{*}$ & & .82 \\
\hline Item 10 & 1.41 & 0.83 & 1.020 & 1.262 & & $.92 *$ & & .85 \\
\hline Item 11 & 1.42 & 0.82 & 1.778 & 1.993 & & & $.79 *$ & .63 \\
\hline Item 12 & 1.42 & 0.81 & 1.832 & 1.353 & & & $.89^{*}$ & .80 \\
\hline Item 13 & 2.61 & 1.15 & -0.178 & -1.246 & & & $.73^{*}$ & .53 \\
\hline Item 14 & 1.61 & 0.92 & 1.054 & -1.151 & & & $.68^{*}$ & .46 \\
\hline Item 15 & 1.54 & 0.84 & 1.253 & 0.551 & & & $.64 *$ & .41 \\
\hline
\end{tabular}

$M$ means, $S D$ standard deviations, $S$ Support, $I$ Interference, $L E$ Lack of Engagement, $S k$ Skewness, $K$ Kurtosis, $\lambda$ factor loading

$* p<.001$ 


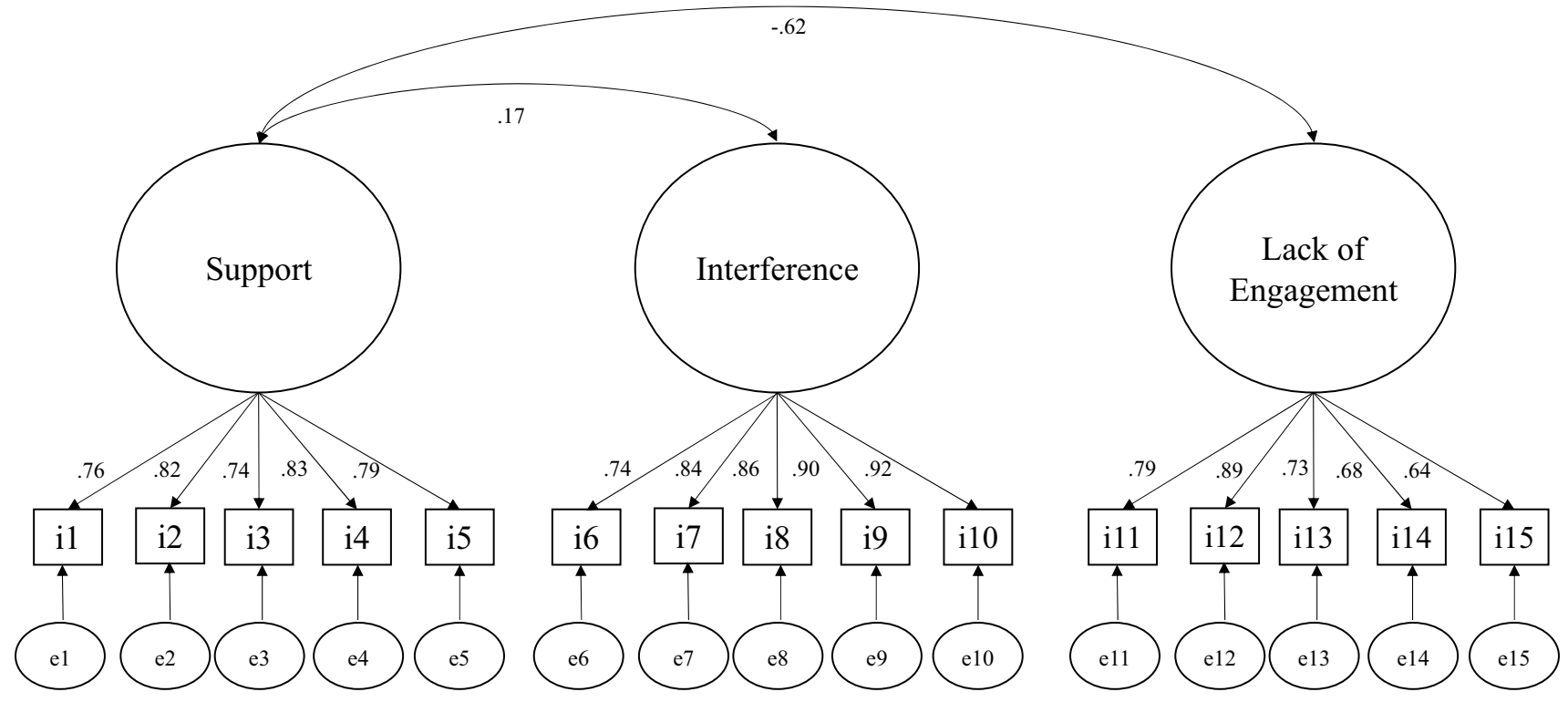

Fig. 2 Graphical representation of the three-dimensional structure of PCB tested with CFA (young adults population)

Table 4 Means, standard deviation, and correlations matrix in young adults population

\begin{tabular}{|c|c|c|c|c|c|c|c|c|c|c|c|}
\hline & 1 & 2 & 3 & 4 & 5 & 6 & 7 & 8 & $\mathrm{M}(\mathrm{SD})$ & $\mathbf{M}_{\text {male }}$ & $\mathrm{M}_{\text {female }}$ \\
\hline 1. Age & - & & & & & & & & - & - & - \\
\hline 2. PCB S & $-.129 *$ & - & & & & & & & $2.50(0.85)$ & $2.48(0.90)$ & $2.51(0.84)$ \\
\hline 3. PCB I & $.172 * *$ & $-123 *$ & - & & & & & & $1.45(0.65)$ & $1.49(0.65)$ & $1.43(0.65)$ \\
\hline 4. PCB LE & $.147 * *$ & $-.467 * *$ & .078 & - & & & & & $1.79(0.66)$ & $1.84(0.64)$ & $1.77(0.66)$ \\
\hline 5. CDDQ LR & -.052 & -.002 & $.191 * *$ & $.203 * *$ & - & & & & $4.34(1.08)$ & $4.10(1.93)$ & $4.44(1.04)$ \\
\hline 6. CDDQ LI & $-.152 * *$ & $-.122 *$ & $.156^{* *}$ & $.296 * *$ & $.485 * *$ & - & & & $4.21(1.90)$ & $4.07(1.93)$ & $4.27(1.89)$ \\
\hline 7. CDDQ II & -.004 & -.038 & $.362 * *$ & $.292 * *$ & $.528 * *$ & $.677 * *$ & - & & $3.04(1.37)$ & $3.08(1.44)$ & $3.03(1.34)$ \\
\hline 8. CDDQ & -.095 & -.077 & $.269 * *$ & $.319 * *$ & $.735 * *$ & $.904 * *$ & $.871 * *$ & - & $3.87(1.24)$ & $3.75(1.33)$ & 3.91(1.19) \\
\hline
\end{tabular}

PCB S Parental Career-related Behaviors Support, PCB I Parental Career-related Behaviors Interference, PCB LE Parental Career-related Behaviors Lack of engagement, $C D D Q$ Career Decision-making Difficulties Questionnaire with $L R$ Lack of readiness, $L I$ Lack of information, and $I I$ Inconsistence of information, $M$ Mean, $S D$ Standard Deviation

$* p<.01, * * p<.001$

confirmed the internal consistency of the instrument also for the university students. Therefore, this adapted version of the PCB proved to be valid for university students in the Italian context.

\section{Discussion}

The present study aimed to test the psychometric characteristics of the Parental Career-related Behaviors questionnaire (PCB) in adolescents and young adults in the Italian context. In Study I, factor structure, reliability and discriminant validity of the PCB were evaluated in the teenage population. In Study II, the same instrument was adapted to the young adult population and its three-dimensional structure was tested. To our knowledge, no previous study assessed the structural validity of the PCB in the university student population. Thus, the second study aimed to cover this lack.

The structure of the Italian versions of the PCB was tested through CFA, which revealed that the PCB three-factor solution has a very good fit to the data and good reliability of each dimension for both teenage and young adult populations. Like the original structure, the first factor includes the five items of the Support dimension, the second factor includes the five items of the Interference dimension, while the third factor includes the five items of the Lack of Engagement dimension. Therefore, our results revealed that 
the PCB can be used equally well by both adolescents and young adults.

Like in Marcionetti and Rossier (2016) and Dietrich and Kracke (2009), in the adolescents' group, positive associations emerged between Lack of engagement and Interference, while a negative association emerged between Support and Lack of engagement. In the university students' group, a negative association emerged between Support and Lack of engagement and a weaker positive association emerged between Support and Interference. The positive relationship between Support and Interference is not in line with previous studies. In the studies by Marcionetti and Rossier (2016) and Dietrich and Kracke (2009), the relationship between these dimensions was negative but it referred to the teenage population. This result should then be understood considering the Italian context, specifically the family models (Barabasch et al., 2015; Biggart \& Walther, 2006; Gal, 2010; León \& Migliavacca, 2013). Italy has been ranked among the countries with a sub-protective transition regime, characterized by insecurity (Tagliabue et al., 2014; Walther, 2006). In this context, individuals depend on the extent of the family support. Probably, strong support could be perceived by young people as interference in their career choices.

Then, the test of the three PCB dimensions' criterion validity was performed by investigating their associations with career decision-making difficulties. In the adolescents' sample, results unexpectedly highlighted that parental Support in making choices was not associated with the career decision-making process. As expected, though, Interference and Lack of engagement were positively associated with Lack of Readiness, Lack of information and Inconsistence of information. In the young adults' sample, Support was negatively associated only with Lack of information, partly confirming our hypotheses, while Interference and Lack of engagement were positively associated with Lack of readiness, Lack of information and Inconsistence of information. The associations established regarding the PCB and CDDQ dimensions confirmed the convergent validity of the instrument. The results emerged taking into account the age variable confirm the hypotheses that, as their age increases, adolescents perceive less support from their family and greater absence or interference in their choices. This result can be explained by considering the increasing independence in the choices that adolescents require of their families. The evidence of the poor relationship between age and the decisionmaking process is not surprising; indeed, several studies argue that the difficulties related to the career decision-making process do not depend on factors such as age or educational level (Martincin \& Stead, 2014). The only relationship emerging between age and Lack of Readiness in the adolescents' sample shows that older students feel more ready to make a career choice, while the relationship between age and Lack of Information in the university students' sample shows that the greater proximity to the world of work helps their perception, having more information useful for their choice. Additionally, these findings indicated that, more than parental support, high levels of lack of engagement and interference are associated with high levels of lack of information and inconsistency of information. These results suggest that parental interference and lack of engagement increase the difficulty of making career decisions both in adolescents and young adults. This evidence is in line with many studies (Guay et al., 2003; Kracke \& Noack, 2005) and supports the assumption that overly controlling parental influence is more likely to cause difficulties in the career decision-making of children (Guerra \& Braungart-Rieker, 1999; Lopez \& Andrews, 1987), while conversely that parents' views on careers is important for adolescents (Otto, 2000). The evidence on the Support dimension may have different explanations. Although lack of engagement or interference are related to career indecision processes, our results showed that the support dimension is not related to career decisionmaking. This implies that support does not play a key role in this process, thus it probably could be more oriented towards creating a good environment for career choices. For example, support could be more related to career exploration, as confirmed by several studies across different research samples (Guan et al., 2015; Phillips et al., 2001; Schultheiss et al., 2001). Furthermore, parental support could affect career decision-making if mediated by other dimensions, for example personal resources (Parola \& Marcionetti, 2021). In the young adults' sample, the dimension of support is related to perceiving more information about careers. This result can be explained by taking into account the specific target: parents are closer to the job market and, in this case, their support can be perceived as a resource for this specific dimension in the decision-making process.

Therefore, more problematic parental behaviors, such as lack of engagement and interference, play a role in career indecision, hindering even more the complicated career decision-making process.

\section{Limitations and Future Directions}

This study is not without limitations. First of all, there is no comparison between parents. The PCB questionnaire did not distinguish between mothers and fathers, but the literature shows differences in the relationships according to the child's and parent's gender (Collins \& Laursen, 2004). The construction and validation of future questionnaires of parent career-related behaviors will have to consider these differences. Secondly, both studies did not investigate the invariance between genders and, specifically for the adolescents' group, the education level (middle school and high school). Unfortunately, the number 
of adolescents and young adults within the two different groups did not allow for the measurement invariance test (Brown, 2015; Kline, 2016; Millsap, 2012). Future investigation will explore the validity of the PCB across male and female groups. Furthermore, future studies will have to take into account convergent and divergent validity, while only criterion validity was tested in this study. Thirdly, other demographic information, such as socioeconomic status, should be considered in other studies; indeed, it could play an important role in the behavior of parents bringing up their children. Unfortunately, the Italian schools that took part in this study did not allow us to collect private information about their students. Fourthly, different interpretations remain to be confirmed, which thing results in possible research exploration by using the $\mathrm{PCB}$, for example investigating the link between the dimension of support and the career decision-making difficulties. Our data suggest that parental support may not be directly linked to the career decision-making process, but further research may study if parental support could have an impact mediated by other psychological variables (i.e. agency, motivation). Furthermore, it could be interesting to analyze the association between parental career-related behaviors and career decision self-efficacy and/or career exploration activities. It would also be interesting to study parental behaviors' effect on long-term career choices and investigate the effect of age on parental career behaviors.

\section{Practical Implications}

This study confirmed that students' perceptions of parents' career-related behaviors could be reliably assessed on three dimensions by applying the PCB also in the Italian context. Moreover, these studies confirm the use of PCB with adolescents in the Italian context and provide the first evidence of the PCB scale as a promising instrument for assessing youth perception of parental career-related behaviors. In our opinion, studying parental career-related behaviors can help researchers to understand the mechanisms of parental influences. Assessing parental career-related behaviors can help adolescents and young adults in their career development and facilitate the career decision-making process. Moreover, this instrument may help career counselors to assess parental influence and develop career interventions. Career guidance may aim to help adolescents and young adults to actively engage in a personal life plan (Fusco et al., 2020, 2021; Parola \& Marcionetti, 2020) involving the family and entrusting it a key role in their support network.
Data Availability The datasets of the current study are available from the corresponding author on reasonable request.

\section{Declarations}

Ethical Approval This study was performed in line with the principles of the Declaration of Helsinki. The questionnaire and methodology for this study was approved by the Human Research Ethics committee of the University of Naples Federico II (Ethics approval number: 20/2019).

Consent to Participate/Publish For the study I, written informed consent was obtained from the parents. For the study II, informed consent was obtained from all individual participants included in the study.

Conflicts of Interest/Competing Interests The authors have no conflicts of interest to declare that are relevant to the content of this article.

Open Access This article is licensed under a Creative Commons Attribution 4.0 International License, which permits use, sharing, adaptation, distribution and reproduction in any medium or format, as long as you give appropriate credit to the original author(s) and the source, provide a link to the Creative Commons licence, and indicate if changes were made. The images or other third party material in this article are included in the article's Creative Commons licence, unless indicated otherwise in a credit line to the material. If material is not included in the article's Creative Commons licence and your intended use is not permitted by statutory regulation or exceeds the permitted use, you will need to obtain permission directly from the copyright holder. To view a copy of this licence, visit http://creativecommons.org/licenses/by/4.0/.

\section{References}

Barabasch, A., Merrill, B., \& Zanazzi, S. (2015). Structural support, networking, and individual survival: Career changes in Italy and Spain. British Journal of Guidance \& Counselling, 43(3), 323336. https://doi.org/10.1080/03069885.2015.1028889

Biggart, A., \& Walther, A. (2006). Coping with yo-yo-transitions: Young adults struggle for support, between family and state in comparative perspective. In C. Leccardi \& E. Ruspini (Eds.), A new youth? Young people, generations and family life (pp. 41-62). Ashgate Publishing.

Blustein, D. L., Walbridge, M. M., Friedlander, M. L., \& Palladino, D. E. (1991). Contributions of psychological separation and parental attachment to the career development process. Journal of Counseling Psychology, 38(1), 39-50. https://doi.org/10.1037/00220167.38.1.39

Brown, T. A. (2015). Confirmatory factor analysis for applied research (2nd ed.). The Guilford Press.

Byrne, B. M. (2010). Structural equation modeling with AMOS. Basic concepts, applications, and programming ( 2 nd ed.). Routledge Academic.

Collins, W. A., \& Laursen, B. (2004). Changing relationships, changing youth: Interpersonal contexts of adolescent development. The Journal of Early Adolescence, 24(1), 55-62. https://doi.org/10. 1177/0272431603260882

Di Fabio, A., \& Palazzeschi, L. (Eds.). (2013). CDDQ - Career Decision-making Difficulties Questionnaire. Giunti O. S.

Dietrich, J., \& Kracke, B. (2009). Career-specific parental behaviors in adolescents' development. Journal of Vocational Behavior, 75 , 109-119. https://doi.org/10.1016/j.jvb.2009.03.005 
Fouad, A. N., Cotter, W. E., Fitzpatrick, E. M., Kantamneni, N., Carter, L., \& Bernfeld, S. (2010). Development and validation of the family influence scale. Journal of Career Assessment, 18, 276-291. https://doi.org/10.1177/1069072710364793

Fusco, L., Sica, L. S., Parola, A., \& Aleni Sestito, L. (2020). Vocational identity flexibility and psychosocial functioning in Italian high school students. International Journal of School \& Educational Psychology. https://doi.org/10.1080/21683603.2020.1841050

Fusco, L., Parola, A., \& Sica, L. S. (2021). Life design for youth as a creativity-based intervention for transforming a challenging World. Frontiers in Psychology, 12, 662072. https://doi.org/10. 3389/fpsyg.2021.662072

Gal, J. (2010). Exploring the extended family of Mediterranean welfare states, or: Did Beveridge and Bismarck take a Mediterranean cruise together? In M. Ajenstadt \& J. Gal (Eds.), Children, gender and families in Mediterranean welfare states (pp. 77-101). Springer.

Gati, I., Krausz, M., \& Osipow, S. (1996). A taxonomy of difficulties in career decision making. Journal of Counseling Psychology, 43, 510-526. https://doi.org/10.1037/0022-0167.43.4.510

Greenhaus, J. H., \& Powell, G. N. (2006). When work and family are allies: A theory of work-family enrichment. Academy of Management Review, 31(1), 72-92. https://doi.org/10.5465/amr.2006. 19379625

Grotevant, H. D., \& Cooper, C. R. (1988). The role of family experience in career exploration: A life-span perspective. In P. B. Baltes, D. L. Featherman, \& R. M. Lerner (Eds.), Life-span development and behavior (Vol. 8, pp. 231-258). Lawrence Erlbaum Associates, Inc.

Guan, Y., Wang, F., Liu, H., Ji, Y., Jia, X., Fang, Z., ... \& Li, C. (2015). Career-specific parental behaviors, career exploration and career adaptability: A three-wave investigation among Chinese undergraduates. Journal of Vocational Behavior, 86, 95-103. https:// doi.org/10.1016/j.jvb.2014.10.007

Guay, F., Senécal, C., Gauthier, L., \& Fernet, C. (2003). Predicting career indecision: A self-determination theory perspective. Journal of Counseling Psychology, 50(2), 165-177. https://doi.org/10. 1037/0022-0167.50.2.165

Guay, F., Ratelle, C. F., Senécal, C., Larose, S., \& Deschênes, A. (2006). Distinguishing developmental from chronic career indecision: Self-efficacy, autonomy, and social support. Journal of Career Assessment, 14, 235-251. https://doi.org/10.1037/00220167.50.2.165

Guerra, A. L., \& Braungart-Rieker, J. M. (1999). Predicting career indecision in college students: The roles of identity formation and parental relationship factors. Career Development Quarterly, 47, 255-266. https://doi.org/10.1002/j.2161-0045.1999.tb00735.x

Halpern, D. F. (2005). Psychology at the intersection of work and family: Recommendations for employers, working families, and policymakers. American Psychologist, 60, 397-409. https://doi. org/10.1037/0003-066X.60.5.397

Hargrove, B. K., Creagh, M. G., \& Burgess, B. L. (2002). Family interaction patterns as predictors of vocational identity and career decision-making self-efficacy. Journal of Vocational Behavior, 61(2), 185-201. https://doi.org/10.1006/jvbe.2001.1848

Hargrove, B. K., Inman, A. G., \& Crane, R. L. (2005). Family interaction patterns, career planning attitudes, and vocational identity of high school adolescents. Journal of Career Development, 31(4), 263-278. https://doi.org/10.1007/s10871-005-4740-1

Hartung, P. J., Porfeli, E. J., \& Vondracek, F. W. (2005). Child vocational development: A review and reconsideration. Journal of Vocational Behavior, 66(3), 385-419. https://doi.org/10.1016/j. jvb.2004.05.006

Hughes, C., \& Thomas, T. (2003). The family's influence on adolescent and young adult career development: Theory, research and practice. Australian Journal of Career Development, 12(2), 38-46. https://doi.org/10.1177/103841620301200206

Johnson, P., Buboltz, W. C., \& Nichols, C. N. (1999). Parental divorce, family functioning, and vocational identity of college students. Journal of Career Development, 26(2), 137-146. https://doi.org/ 10.1023/A:1022958310964

Keller, B. K., \& Whiston, S. C. (2008). The role of parental influences on young adolescents' career development. Journal of Career Assessment, 16(2), 198-217. https://doi.org/10.1177/1069072707 313206

Kenny, M. E., \& Bledsoe, M. (2005). Contributions of the relational context to career adaptability among urban adolescents. Journal of Vocational Behavior, 66(2), 257-272. https://doi.org/10.1016/j. jvb.2004.10.002

Kline, R. B. (2011). Principles and practice of structural equation modeling (3rd ed.). The Guilford Press.

Kline, R. B. (2016). Principles and practice of structural equation modeling (4th ed.). The Guilford Press.

Kracke, B. (1997). Parental behaviors and adolescents' career exploration. Career Development Quarterly, 45, 341-350. https://doi.org/ 10.1002/j.2161-0045.1997.tb00538.x

Kracke, B., \& Noack, P. (2005). Die Rolle der Eltern für die Berufsorientierung von Jugendlichen [The role of parents in adolescents' career development]. In B. H. Schuster, H.-P. Kuhn, \& H. Uhlendorff (Eds.), Entwicklung in sozialen Beziehungen (pp. 169-193). Lucius \& Lucius.

Kush, K., \& Cochran, L. (1993). Enhancing a sense of agency through career planning. Journal of Counseling Psychology, 40(4), 434-439. https://doi.org/10.1037/0022-0167.40.4.434

Lent, R. W., Brown, S. D., Nota, L., \& Soresi, S. (2003). Testing social cognitive interest and choice hypotheses across Holland types in Italian high school students. Journal of Vocational Behavior, 62(1), 101-118. https://doi.org/10.1016/S00018791(02)00057-X

León, M., \& Migliavacca, M. (2013). Italy and Spain: Still the case of familistic welfare models? Population Review, 52(1), 25-42. https://doi.org/10.1353/prv.2013.0001

Li, Y., Guan, Y., Wang, F., Zhou, X., Guo, K., Jiang, P., ... \& Fang, Z. (2015). Big-five personality and BIS/BAS traits as predictors of career exploration: The mediation role of career adaptability. Journal of Vocational Behavior, 89, 39-45. https://doi.org/ 10.1016/j.jvb.2015.04.006

Lopez, F. G., \& Andrews, S. (1987). Career indecision: A family systems perspective. Journal of Counseling \& Development, 65(6), 304-307. https://doi.org/10.1002/j.1556-6676.1987.tb01291.x

Marcionetti, J., \& Rossier, J. (2016). The parental career-related behaviors (PCB) questionnaire: Italian validation. Testing, Psychometrics, Methodology in Applied Psychology, 23, 347-363. https:// doi.org/10.4473/TPM23.3.6

Martincin, K. M., \& Stead, G. B. (2014). Five-factor model and difficulties in career decision making: A meta-analysis. Journal of Career Assessment, 23(1), 3-19. https://doi.org/10.1177/10690 72714523081

Medsker, G. J., Williams, L. J., \& Holahan, P. J. (1994). A review of current practices for evaluating causal models in organizational behavior and human resources management research. Journal of Management, 20(2), 439-464. https://doi.org/10.1016/01492063(94)90022-1

Millsap, R. E. (2012). Statistical approaches to measurement invariance. Routledge.

Neuenschwander, M. P. (2008). Elternunterstützung im Berufswahlprozess [Parental support in the career choice process]. In D. Läge \& A. Hirschi (Eds.), Berufliche Übergänge: Psychologische Grundlagen der Berufs, Studien und Laufbahnberatung (pp. 135-154). LIT-Verlag. 
Otto, L. B. (2000). Youth perspectives on parental career influence. Journal of Career Development, 27, 111-118. https://doi.org/10. 1023/A:1007848600942

Paa, H. K., \& Mcwhirter, E. H. (2000). Perceived influences on high school students' current career expectations. The Career Development Quarterly, 49(1), 29-44. https://doi.org/10.1002/j.21610045.2000.tb00749.x

Parola, A., \& Marcionetti, J. (2020). Career Orientation: a qualitative study of the best practices in the Swiss context. Mediterranean Journal of Clinical Psychology, 8(3). https://doi.org/10.6092/ 2282-1619/mjcp-2552

Parola, A., \& Marcionetti, J. (2021). Career decision-making difficulties and life satisfaction: The role of career-related parental behaviors and career adaptability. Journal of Career Development. https://doi.org/10.1177/2F0894845321995571

Penick, N. I., \& Jepsen, D. A. (1992). Family functioning and adolescent career development. The Career Development Quarterly, 40(3), 208-222. https://doi.org/10.1002/j.2161-0045.1992.tb003 27. $\mathrm{x}$

Phillips, S. D., Christopher-Sisk, E. K., \& Gravino, K. L. (2001). Making career decisions in a relational context. The Counseling Psychologist, 29(2), 193-214. https://doi.org/10.1177/0011000001 292002

Ryan, N. E., Solberg, V. S., \& Brown, S. D. (1996). Family dysfunction, parental attachment, and career search self-efficacy among community college students. Journal of Counseling Psychology, 43, 84-89. https://doi.org/10.1037/0022-0167.43.1.84

Schultheiss, D. E. P. (2006). The interface of work and family life. Professional Psychology: Research and Practice, 37, 334-341. https://doi.org/10.1037/0735-7028.37.4.334

Schultheiss, D. E. P., Kress, H. M., Manzi, A. J., \& Glasscock, J. M. J. (2001). Relational influences in career development: A qualitative inquiry. The Counseling Psychologist, 29(2), 216-241. https://doi. org/10.1177/0011000001292003

Tagliabue, S., Lanz, M., \& Beyers, W. (2014). The transition to adulthood around the Mediterranean: Contributions of the special issue. Journal of Adolescence, 37(8), 1405-1408. https://doi.org/ 10.1016/j.adolescence.2014.09.001
Tracey, T. J., \& Darcy, M. (2002). An idiothetic examination of vocational interests and their relation to career decidedness. Journal of Counseling Psychology, 49(4), 420-427. https://doi.org/10.1037/ 0022-0167.49.4.420

Tracey, T. J., Lent, R. W., Brown, S. D., Soresi, S., \& Nota, L. (2006). Adherence to RIASEC structure in relation to career exploration and parenting style: Longitudinal and idiothetic considerations. Journal of Vocational Behavior, 69(2), 248-261. https://doi.org/ 10.1016/j.jvb.2006.02.001

Turner, S. L., \& Lapan, R. T. (2005). Evaluation of an intervention to increase non-traditional career interests and career-related selfefficacy among middle-school adolescents. Journal of Vocational Behavior, 66(3), 516-531. https://doi.org/10.1016/j.jvb.2004.02.005

Vignoli, E., Croity-Belz, S., Chapeland, V., de Fillipis, A., \& Garcia, M. (2005). Career exploration in adolescents: The role of anxiety, attachment, and parenting style. Journal of Vocational Behavior, 67, 153-168. https://doi.org/10.1016/j.jvb.2004.08.006

Walther, A. (2006). Regimes of youth transitions: Choice, flexibility and security in young people's experiences across different European contexts. Young, 14(2), 119-139. https://doi.org/10.1177/ 2F1103308806062737

Whiston, S. C., \& Keller, B. K. (2004). The influences of the family of origin on career development: A review and analysis. The Counseling Psychologist, 32, 493-568. https://doi.org/10.1177/ 0011000004265660

Wolfe, J. B., \& Betz, N. E. (2004). The relationship of attachment variables to career decision-making self-efficacy and fear of commitment. The Career Development Quarterly, 52(4), 363-369. https:// doi.org/10.1002/j.2161-0045.2004.tb00952.x

Zhao, X., Lim, V. K., \& Teo, T. S. (2012). The long arm of job insecurity: Its impact on career-specific parenting behaviors and youths' career self-efficacy. Journal of Vocational Behavior, 80(3), 619628. https://doi.org/10.1016/j.jvb.2012.01.018

Publisher's note Springer Nature remains neutral with regard to jurisdictional claims in published maps and institutional affiliations. 